\title{
PENERAPAN PEMBELAJARAN KOOPERATIF DENGAN PENDEKATAN STRUKTURAL THINK PAIR SHARE UNTUK MENINGKATKAN KEMAMPUAN PEMECAHAN MASALAH MAHASISWA
}

\author{
Depi Fitraini ${ }^{1}$, Irma Fitri ${ }^{2}$ \\ 1,2, Program Studi Pendidikan Matematika, Fakultas Tarbiyah dan Keguruan, UIN Sultan Syarif Kasim Riau \\ ${ }^{1}$ Email: depi.fitraini@uin-suska.ac.id \\ ${ }^{2}$ Email: Irma.fitri@uin-suska.ac.id
}

\begin{abstract}
This research aims to see whether the Think Pair Share strategy can improve students' mathematical problem solving abilities in Basic Linear Algebra courses. This research was conducted on VF students of Mathematics Education Program UIN Sulthan Syarif Kasim Riau. This type of research is Action Research. Data collection in this research using documentation, observation and test. This research consists of two cycles consisting of planning, implementation, observation and reflection activities. In the first cycle, the success in the learning process has been achieved which is summarized in the observation sheet of lecturer and student activities but on the success of student problem solving ability has not been achieved. In the first cycle, only $62 \%$ of students are complete while in cycle II $81 \%$ of students complete in problem-solving ability. The results showed that cooperative learning with structural approach Think Pair Share can improve student learning outcomes on problem solving abilities.
\end{abstract}

Keywords: Think Pair Share, Problem Solving Abilities, Action Research

\begin{abstract}
Abstrak
Penelitian ini bertujuan untuk melihat apakah strategi Think Pair Share dapat meningkatkan kemampuan pemecahan masalah matematika mahasiswa pada mata kuliah Aljabar Linear Dasar. Penelitian ini dilakukan pada mahasiswa semester VF Program Studi Pendidikan Matematika UIN Sulthan Syarif Kasim Riau. Jenis penelitian ini adalah Action Research. Pengambilan data pada penelitian ini menggunakan dokumentasi, observasi dan tes. Penelitian ini terdiri dari dua siklus yang terdiri dari kegiatan perencanaan, pelaksanaan, pengamatan dan refleksi. Pada siklus I, keberhasilan dalam proses pembelajaran sudah tercapai yang terangkum dalam lembar pengamatan aktivitas dosen dan mahasiswa namun pada keberhasilan kemampuan pemecahan masalah mahasiswa belum tercapai. Pada siklus I, hanya 62\% mahasiswa yang tuntas sedangkan pada siklus II 81\% mahasiswa tuntas dalam kemampuan pemecahan masalah. Hasil penelitian menunjukkan bahwa pembelajaran kooperatif dengan pendekatan struktural Think Pair Share dapat meningkatkan hasil belajar mahasiswa pada kemampuan pemecahan masalah.
\end{abstract}

Kata Kunci: Think Pair Share, Kemampuan Pemecahan Masalah, Action Research

Matematika adalah salah satu mata pelajaran yang sudah tidak asing lagi dalam dunia pendidikan, karena matematika memiliki peranan yang sangat penting dalam pengembangan kemampuan berfikir. Matematika sudah diajarkan dalam jenjang pendidikan mulai dari tingkat pendidikan dasar hingga ke perguruan tinggi. Salah satu tujuan dari pembelajaran matematika adalah dapat memecahkan masalah, hal ini sesuai dengan tujuan dari pembelajaran matematika dalam Depdiknas (2006), yaitu:

1. Memahami konsep matematika, menjelaskan keterkaitan antar konsep dan mengaplikasikan konsep atau algoritma secara luwes, akurat, efisien dan tepat dalam pemecahan masalah 
2. Menggunakan penalaran pada pola dan sifat, melakukan manipulasi matematika dalam membuat generalisasi, menyusun bukti atau menjelaskan gagasan dan pernyataan matematika.

3. Memecahkan masalah yang meliputi kemampuan memahami masalah, merancang model matematika, menyelesaikan model dan menafsirkan solusi yang diperoleh.

4. Mengkomunikasikan gagasan dengan symbol, tabel atau media lain untuk memperjelas keadaan atau masalah.

5. Memiliki sikap menghargai kegunaan matematika dalam kehidupan, yaitu memiliki rasa ingin tahu, perhatian, dan minat dalam mempelajari matematika, serta sikap ulet dan percaya diri dalam pemecahan masalah.

Merujuk kepada tujuan pembelajaran matematika tersebut, sudah sepantasnya kemampuan pemecahan masalah matematis mendapat perhatian dan perlu dikembangkan dengan cara mengaktifkan siswa, menjadikan pembelajaran yang mungkin selama ini teacher center menjadi student center dengan menerapkan berbagai metode atau stretegi pembelajaran yang bervariasi. Tidak berkembangnya kemampuan pemecahan masalah bukan sepenuhnya kesalahan dari siswa, tetapi kesalahan juga terdapat dari guru yang cenderung menerapkan pembelajaran konvensional. Kemampuan pemecahan masalah memang harus ditumbuhkembangkan pada siswa mengingat begitu pentingnya posisi kemampuan pemecahan masalah dalam matematika. Kemampuan pemecahan masalah menurut Polya dalam Heris Hendriana, dkk (2017) mengemukakan bahwa pemecahan masalah adalah suatu usaha mencari jalan keluar dari suatu tujuan yang tidak begitu mudah untuk dicapai. Krulik dan Rudnik mengemukakan bahwa pemecahan masalah merupakan proses dimana individu menggunakan pengetahuan, keterampilan dan pemahaman yang telah diperoleh untuk menyelesaikan masalah pada situasi yang belum dikenalnya. Istilah pemecahan masalah mengandung arti mencari cara metode atau pendekatan penyelesaian melalui beberapa kegiatan antara lain mengamati, memahami, mencoba, menduga, menemukan, dan meninjau kembali. Ditinjau dari segi tujuannya, istilah masalah matematis dalam (Heris Hendriana, dkk: 2017), Polya mengklasifikasikan masalah matematis dalam dua jenis, yaitu:

1. Masalah untuk menemukan secara teoritis atau praktis, abstrak atau konkrit, termasuk tekateki. Bagian utama dari suatu masalah adalah apa yang dicari, bagaimana data yang diketahui, dan bagaimana syaratnya. Ketiga bagian utama tersebut merupakan landasan untuk dapat menyelesaikan masalah jenis ini.

2. Masalah untuk membuktikan yang menunjukkan bahwa suatu pernyataan itu benar, salah atau tidak kedua-duanya. Bagian utama dari masalah ini adalah hipotesis dan konklusi dari suatu teorema yang harus dibuktikan kebenarannya. Kedua bagian utama tersebut sebagai landasan utama untuk dapat menyelesaikan maslalaj jenis ini. 
Gagne (Russefendi, 2006) mengemukakan ada lima langkah yang harus dilakukan dalam menyelesaikan masalah yaitu:

1. Menyajikan masalah dalam bentuk yang lebih jelas

2. Menyatakan masalah dalam bentuk yang operasional (dapat dipecahkan)

3. Menyusun hipotesis-hipotesis alternative dan prosedur kerja yang diperkirakan baik untuk dipergunakan dalam memecahkan masalah itu.

4. Mentes hipotesis dan melakukan kerja untuk memperoleh hasilnya (pengumpulan data, pengolahan data dan lain-lain), hasilnya mungkin lebih dari satu.

5. Memeriksa kembali (mengecek) apakah hasil yang diperoleh itu benar, atau mungkin memilih alternative pemecahan yang baik.

Mahasiswa Program Studi Pendidikan Matematika merupakan calon guru yang dipersiapkan untuk mengajarkan bidang studi matematika. Pada kurikulum Program Studi Pendidikan Matematika terdapat mata kuliah Aljabar Linear Dasar dengan bobot 3 SKS. Materi pada mata kuliah Aljabar Linear Dasar ini terdiri dari matriks, operasi matriks, menyelesaikan masalah sistem persamaan linear dengan matriks, vektor dan sebagainya, dimana materi-materi tersebut mencakup kemampuan pemecahan masalah dan juga merupakan bagian dari materi pada bidang studi matematika tingkat SLTA. Oleh karena itu sudah sepatutnya mahasiswa harus memiliki kemampuan pemecahan masalah yang baik dan menguasai materi pada mata kuliah tersebut agar nantinya ketika mahasiswa sudah menjadi guru matematika mereka sudah memiliki bekal ilmu yang cukup untuk disampaikan kepada siswanya dan mampu memfasilitasi kemampuan pemecahan masalah siswa.

Mahasiswa Pendidikan Matematika semester V terdiri dari enam kelas. Salah satu kelas, pada mata kuliah Aljabar Linear Dasar diampu oleh peneliti yaitu pada kelas VF. Pada kelas ini kemampuan pemecahan masalaha mahasiswa rendah, hal ini terlihat dari keaktifan siswa yang kurang dalam proses pembelajaran berlangsung, ketika diberikan soal yang berbeda dengan contoh mahasiswa tidak bias mengerjakan, mahasiswa tidak mampu memahami soal dengan baik dan tidak mampu mencari strategi penyelesaian masalah. Untuk mengatasi rendahnya kemampuan pemecahan masalah mahasiswa tersebut, dosen sudah melakukan berbagai upaya yaitu dengan belajar kelompok, diskusi, tanya jawab, namun kemampuan pemecahan masalah belum memberikan hasil yang diharapkan.

Salah satu pembelajaran yang dapat menunjang kemampuan pemecahan masalah mahasiswa adalah dengan penerapan pembelajaran kooperatif dengan pendekatan struktural Think Pair Share. Pembelajaran kooperatif merupakan model pembelajaran yang menggunakan sistem pengelompokan. Menurut Anita Lie (2007) pembelajaran kooperatif disebut dengan istilah pembelajaran gotong royong, yaitu sistem pembelajaran yang memberi kesempatan kepada peserta didik untuk bekerja sama dengan siswa lain dalam tugas-tugas yang terstruktur .Menurut Nurhadi dan Senduk (Made Wena, 2009) pembelajaran kooperatif adalah pembelajaran yang secara sadar menciptakan interaksi yang silih asah sehingga sumber belajar bagi siswa bukan hanya guru saja, tetapi juga semua siswa. 
Dapat disimpulkan bahwa pembelajaran kooperatif adalah belajar bersama dalam kelompok untuk menyelesaikan tugas-tugas tertentu dengan adanya bimbingan guru dan interaksi yang terbuka antar sesame siswa.

Model pembelajaran kooperatif saat ini adalah model yang paling banyak digunakan untuk mewujudkan kegiatan belajar mengajar yang berpusat pada siswa, terutama untuk mengatasi permasalahan yang ditemukan dalam mengaktifkan siswa dan siswa yang sulit bekerja sama dengan orang lain. Hal ini sejalan dengan pendapat Johnson (Isjoni, 2010) yang menyatakan bahwa pembelajaran kooperatif juga menghasilkan peningkatan kemampuan akademik, meningkatkan kemampuan berfikir kritis, membentuk hubungan persahabatan, menimba berbagai informasi, belajar menggunakan sopan santun, meningkatkan motivasi siswa, memperbaiki sikap terhadap sekolah dan belajar mengurangi tingkah laku yang kurang baik serta membantu siswa dalam menghargai pokok pikiran orang lain. Pendekatan terkahir dalam pembelajaran kooperatif adalah pendekatan structural yang dikembangkan oleh Spencer Kagan dkk. Meskipun memiliki banyak persamaan dengan pendekatan lain, namun pendekatan ini memberi penekanan pada penggunaan struktur tertentu yang dirancang untuk mempengaruhi pola interaksi siswa. Struktur yang dikembangkan ini dimaksud sebagai alternatif terhadap struktur kelas tradisional. Ada dua macam struktur yang dikembangkan untuk meningkatkan perolehan isi akademik yang salah satunya adalah Think Pair Share.

Think Pair Share dikembangkan oleh Frank Lyman dari university Maryland pada yahun 1985. Struktur ini menghendaki siswa belajar saling membantu dalam kelompok kecil yang heterogen baik secara akademik maupun jenis kelamin. Dengan kelompok kecil ini diharapkan siswa bekerja untuk menyelesaikan tugas-tugas akademik dan semua anggota kelompok akan merasa terlibat didalamnya dan akan meningkatkan hasil belajar siswa. Adapun tahapan dalam pembelajaran Think Pair Share disajikan pada tabel 1 berikut ini:

Tabel 1. Tahapan Think Pair Share

\begin{tabular}{|l|l|}
\hline \multicolumn{1}{|c|}{ Fase } & \multicolumn{1}{|c|}{ Deskripsi } \\
\hline Thinking & $\begin{array}{l}\text { Guru mengajukan suatu permasalahan yang merangsang kemampuan } \\
\text { berfikir siswa. Siswa memikirkan jawaban dari permasalahan yang } \\
\text { diajukan secara mandiri }\end{array}$ \\
\hline Pairing & $\begin{array}{l}\text { Guru mengarahkan siswa untuk berpasangan dan mendiskusikan apa yang } \\
\text { telah dipikirkan }\end{array}$ \\
\hline Sharing & Siswa berbagi pengetahuan yang diperoleh dari hasil diskusi di depan kelas \\
\hline
\end{tabular}

Sumber: Karuni Eka Lestari dan Mokhammad Ridwan (2017)

Berdasarkan tiga tahapan Think Pair Share tersebut, maka pembelajaran akan jauh lebih menyenangkan karena mahasiswa tidak bekerja sendiri-sendiri dan saling membantu antara mahasiswa dalam menyelesaikan masalah. Dengan tahapan demikian, maka strategi Think Pair Share 
diharapkan mampu untuk meningkatkan kemampuan pemecahan masalah mahasiswa dalam mata kuliah Aljabar Linear Dasar. Salah satu keunggulan teknik ini adalah dapat mengoptimalkan partisipasi siswa mengeluarkan pendapat dan meningkatkan pengetahuan siswa (Buchari Alma, dkk, 2009).

\section{METODOLOGI PENELITIAN}

Penelitian ini dilaksanakan pada Program Studi Pendidikan Matematika UIN SUSKA RIAU semester VF tahun ajaran 2017/2018 yang berjumlah 26 orang. Jenis penelitian yang digunakan adalah Action Research atau penelitian tindakan kelas. Igak Wardani (2007) mengatakan bahwa penelitian tindakan kelas adalah penelitian yang dilakukan oleh guru di dalam kelasnya sendiri, dengan tujuan untuk memperbaiki kinerjanya sebagai guru sehingga hasil belajar siswa meningkat. Dalam penelitian ini hasil belajar siswa yang dimaksud adalah kemampuan pemecahan masalah mahasiswa pada mata kuliah Aljabar Linear Dasar. Penelitian tindakan kelas ditujukan untuk memberikan andil pada penyelesaian masalah praktis dalam situasi problematic yang mendesak.

Teknik pengumpulan data yang digunakan adalah tes kemampuan pemecahan masalah di setiap akhir siklus tindakan yang disesuaikan dengan indikator pemecahan masalah. Instrumen yang digunakan dalam penelitian ini adalah Rencana Pelaksanaan Pembelajaran (RPP), Lembar Kerja Mahasiswa (LKM) dan lembar obsevasi aktivitas mahasiswa dan dosen. Kegiatan observasi dilakukan guna untuk melihat kegiatan dosen dan mahasiswa selama proses pembelajaran. Teknik analisis data yang digunakan dalam penelitian ini adalah analisis statistik deskriptif. Satistik deskriptif adalah statistik yang berfungsi untuk mendeskripsikan atau memberi gambaran terhadap obyek yang diteliti melalui data sampel atau populasi sebagaimana adanya, tanpa melakukan analisis dan membuat kesimpulan yang berlaku untuk umum (Sugiyono, 2012).

Adapun langkah-langkah yang ditempuh dalam penelitian tindakan kelas, menurut Kurt Lewin terdiri dari empat komponen, yaitu: (1) perencanaan (planning), (2) pelaksanaan (implementation), (3) pengamatan (observing), (4) refleksi (reflecting). Keempat komponen tersebut membentuk suatu siklus, dan dalam pelaksanaannya kemungkinan dapat membentuk lebih dari satu siklus yang mencakup keempat komponen tersebut. Kriteria yang menjadi acuan dalam penentuan sukses atau tidak dalam setiap tindakan yang dilakukan dalam satu siklus pada penelitian ini ada dua indikator, yaitu keberhasilan proses pembelajaran dan keberhasilan hasil belajar mahasiswa pada kemampuan pemecahan masalah.

\section{HASIL PENELITIAN DAN PEMBAHASAN}

Kegiatan awal yang dilakukan sebelum tindakan adalah perencanaan yaitu menyiapkan materi pelajaran, menyusun rencana pelaksanaan pembelajaran yang sesuai, menyiapkan lembar observasi aktivitas dosen dan mahasiswa, menyiapkan Lembar Kerja Mahasiswa (LKM) dan menyiapkan tes akhir untuk mengukur kemampuan pemecahan masalah mahasiswa setelah tindakan. Pada 
pelaksanaan kegiatan, sesuai dengan pembelajaran yang telah direncanakan terdiri dari dua pertemuan untuk setiap siklus. Pada setiap pertemuan terdiri dari tiga tahapan. Tahap pertama yaitu think, pada tahap ini mahasiswa menyelesaikan masalah pada LKM secara individu atau mandiri. Tahap kedua yaitu pair, pada tahap ini dosen meminta mahasiswa secara berpasangan untuk menyelesaikan masalah pada LKM. Tahap yang ketiga yaitu share, pada tahap ini mahasiswa diminta untuk mempresentasikan hasil diskusi yang telah diperoleh pada tahap pair di depan kelas dan mahasiswa yang lain saling menanggapi. Selama kegiatan pembelajaran berlangsung, peneliti II mengamati tindakan yang dilakukan oleh dosen dan mahasiswa dengan mengisi lembar pengamatan yang telah disiapkan. Keberhasilan tindakan yang dilakukan ditentukan oleh dua kategori, yaitu kategori keberhasilan proses pembelajaran yang ditentukan dengan menggunakan lembar observasi kativitas dosen dan mahasiswa yang dilakukan oleh peneliti II. Hasil pengamatan dianalisis dengan menggunakan analisis persentase. Jumlah skor perolehan masing-masing indikator disebut jumlah skor, sedangkan jumlah skor ideal masing-masing indikator dosebut skor maksimal. Persentase skor perolehan diperoleh dengan cara:

$$
\text { persentaseskorperolehan }(S P)=\frac{\text { jumlahskor }}{\text { skormaksimal }} \times 100 \%
$$

Kriteria taraf keberhasilan proses tindakan ditentukan sebagai berikut:

1. Proses pembelajaran dikatakan sangat baik, jika persentase Skor Perolehan (SP) lebih dari $75 \%$ dan kurang dari atau sama dengan $100 \%$.

2. Proses pembelajaran dikatakan baik, jika persentase Skor Perolehan (SP) lebih dari 50\% dan kurang dari atau sama dengan $75 \%$.

3. Proses pembelajaran dikatakan cukup baik, jika persentase Skor Perolehan (SP) lebih dari $25 \%$ dan kurang dari atau sama dengan $50 \%$.

4. Proses pembelajaran dikatakan kurang baik, jika persentase Skor Perolehan (SP) lebih dari $0 \%$ dan kurang dari atau sama dengan $25 \%$.

Adapun kriteria keberhasilan proses pembelajaran setiap siklus tindakan dikatakan berhasil apabila hasil pengamatan dosen dan mahasiswa minimal pada kategori baik. Kriteria keberhasilan kemampuan pemecahan masalah mahasiswa ditentukan oleh tes akhir kemampuan pemecahan masalah yaitu jika $\geq 80 \%$ dari seluruh jumlah mahasiswa mencapai nilai $\geq 65$.

Hasil pengamatan aktivitas dosen selama proses pembelajaran disajikan pada tabel 2 berikut ini: 
Tabel 2. Hasil Pengamatan Aktivitas Dosen

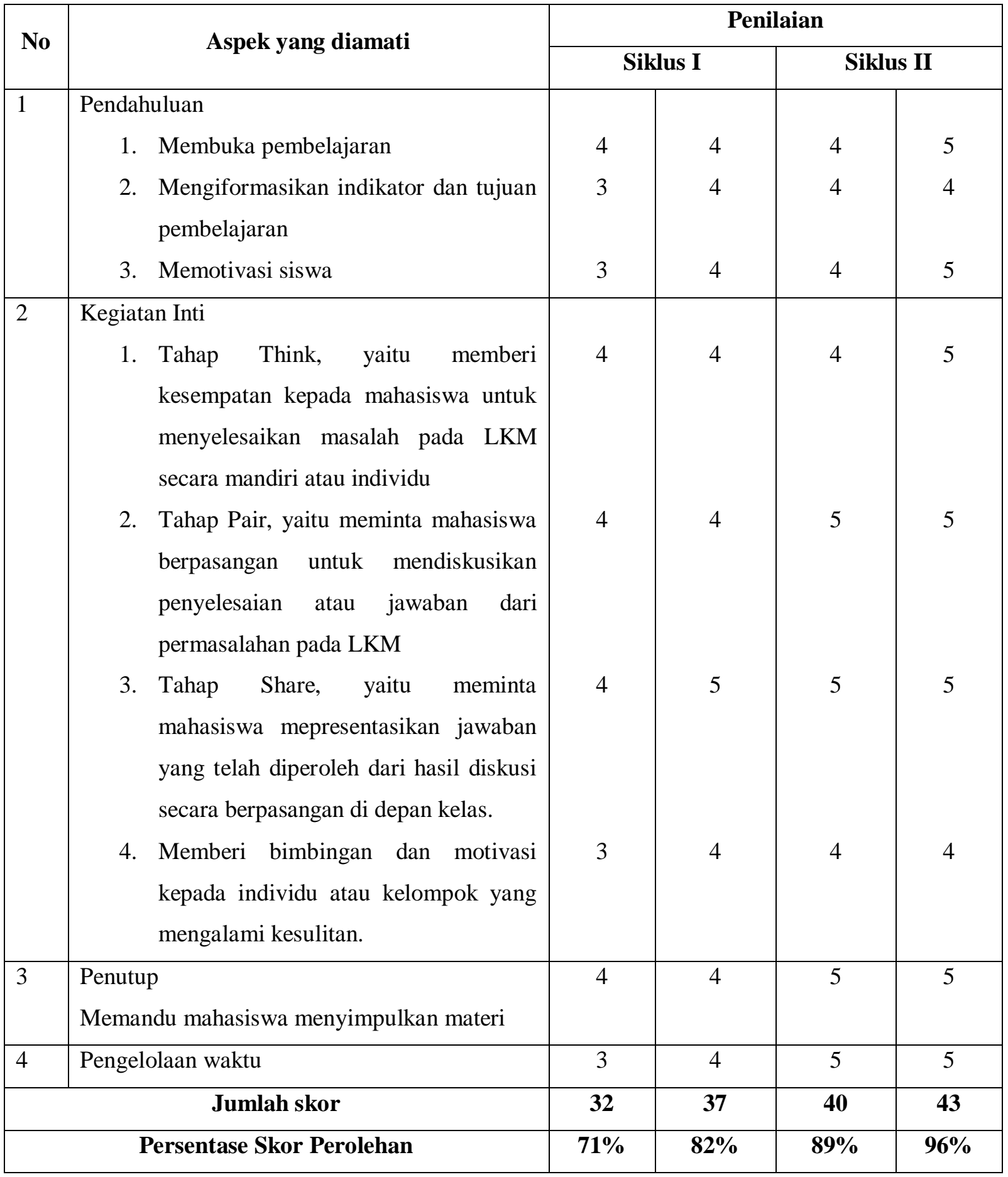

Adapun tabel aktivitas mahasiswa selama proses pembelajaran berlangsung disajikan tabel 3 berikut ini: 
Tabel 3. Hasil Pengamatan Aktivitas Mahasiswa

\begin{tabular}{|c|c|c|c|c|c|}
\hline \multirow{2}{*}{ No } & \multirow{2}{*}{ Aspek yang diamati } & \multicolumn{4}{|c|}{ Penilaian } \\
\hline & & \multicolumn{2}{|c|}{ Siklus I } & \multicolumn{2}{|c|}{ Siklus II } \\
\hline 1 & $\begin{array}{l}\text { Pendahuluan } \\
\text { Mahasiswa menjelaskan penjelasan } \\
\text { guru }\end{array}$ & 3 & 4 & 4 & 5 \\
\hline 2 & $\begin{array}{l}\text { Kegiatan Inti } \\
\text { 1. Tahap Think, yaitu mahasiswa } \\
\text { menyelesaikan masalah pada } \\
\text { LKM secara individu } \\
\text { 2. Tahap Pair, yaitu mahasiswa } \\
\text { berpasangan mendiskusikan } \\
\text { masalaha pada LKM } \\
\text { 3. Tahap Share, yaitu mahasiswa } \\
\text { berpasangan mendiskusikan } \\
\text { jawaban atau hasil diskusi di } \\
\text { depan kelas } \\
\text { 4. Mahasiswa saling menanggapi }\end{array}$ & 4 & 4 & 5 & 5 \\
\hline 3 & $\begin{array}{l}\text { Penutup } \\
\text { Mahasiswa menyimpulkan materi } \\
\text { pembelajaran }\end{array}$ & 3 & 4 & 5 & 5 \\
\hline & Jumlah skor & 19 & 23 & 26 & 28 \\
\hline & Persentase perolehan skor & $63 \%$ & $77 \%$ & $87 \%$ & $93 \%$ \\
\hline
\end{tabular}

Berdasarkan data pengamatan untuk aktivitas dosen pada siklus I sudah mencapai kategori baik dengan persentase perolehan skor $\geq 71 \%$. Pada pengamatan aktivitas pada siklus I juga sudah pada kategori baik dengan persentase perolehan skor $\geq 63 \%$. Namun pada hasil tes kemampuan pemecahan masalah pada mata kuliah Aljabar Linear Dasar pada siklus I menunjukkan bahwa dari 26 mahasiswa terdapat 10 mahasiswa yang tidak tuntas dengan nilai $<65$ atau hanya $62 \%$ mahasiswa yang tuntas. Dengan demikian siklus harus dilanjutkan karena keberhasilan pada siklus I hanya pada proses pembelajaran namun tidak pada hasil kemampuan pemecahan masalah mahasiswa. Pada siklus II juga terdiri dari 2 pertemuan. Setelah siklus II selesai, dilakukan refleksi untuk menentukan apakah siklus perlu dilanjutkan atau tidak. Berdasarkan tabel 2 dan tabel 3, aktivitas dosen dan mahasiswa selama proses pembelajaran berlangsung juga sudah menunjukkan pada kategori baik dengan persentase perolehan skor $\geq 82 \%$ untuk aktivitas dosen dan $\geq 87 \%$ untuk aktivitas mahasiswa. Tes kemampuan pemecahan masalah pada siklus II juga mengalami peningkatan. Dari 26 mahasiswa, hanya 5 mahasiswa yang memperoleh nilai $<65$ atau $81 \%$ mahasiswa pada kategori tuntas. Artinya keberhasilan pada proses pembelajaran dan hasil kemampuan pemecahan masalah mahasiswa sudah tercapai, sehingga siklus tidak perlu dilanjutkan.

\section{KESIMPULAN}

Berdasarkan hasil dan pembahasan penelitian, dapat disimpulkan bahwa pelaksanaan pembelajaran kooperatif dengan pendekatan Struktural Think Pair Share dapat meningkatkan kemampuan 
pemecahan masalah mahasiswa pada mata kuliah Aljbar Linear Dasar pada mahasiswa semester VF. Hal ini ditunjukkan oleh keberhasilan dalam proses pembelajaran untuk setiap siklusnya dan keberhasilan pada hasil kemampuan pemecahan masalah mahasiswa dalam menyelesaikan soal yang diberikan pada akhir siklus tindakan. Berdasarkan hasil tersebut peneliti menyarankan kepada dosen dan juga guru untuk mecoba menerapkan pendekatan Think Pair Share untuk meningkatkan hasil belajar mahasiswa atau siswa.

\section{REFERENSI}

Astuti, A. (2016). Pengaruh Model Pembelajaran Kooperatif Tipe Two Stay Two Stray (Tsts) Terhadap Hasil Belajar Matematika Siswa Kelas Vii Smp Negeri 2 Bangkinang Kota. Jurnal Cendekia : Jurnal Pendidikan Matematika, (2), 11-28. Retrieved From Http://Journal.Stkiptam.Ac.Id/Index.Php/Cendekia/Article/View/626

Alma, Buchari. (2009). Guru Profesional. Bandung: Alfabeta.

Depdiknas. (2006). Kurikulum Tingkat Satuan Pendidikan. Jakarta: Depdiknas

Eka Lestari, Karunia dan Mokhammad Ridwa. (2017). Penelitian Pendidikan Matematika. Bandung: Refika Aditama

Hendriana, Heris., dkk. (2017). Hard Skill \& Soft Skill. Bandung: PT Refika Aditama.

Isjoni. (2010). Cooperatif Learning. Bandung: Alfabeta.

Lie, Anita. (2007). Cooperatif Learning. Jakarta: Grasindo.

Russefendi. (2006). Pengantar Kepada Membantu Guru Mengembangkan Kompetensinya Dalam Pengajaran Matematika Untuk Meningkatkan CBSA. Bandung: Tarsito.

Sugiyono. (2012). Statistik Untuk Penelitian. Bandung: Alfabeta.

Wena, Made. (2009). Stategi Pembelajaran Inovatif Kontemporer. Jakarta: Bumi Aksara.

Zulfah, Z. (2017). Analisis Kesalahan Peserta Didik Pada Materi Persamaan Linear Dua Variabel Di Kelas Viii Mts Negeri Sungai Tonang. Jurnal Cendekia : Jurnal Pendidikan Matematika, 1(1), 1-5. Retrieved From Http://Journal.Stkiptam.Ac.Id/Index.Php/Cendekia/Article/View/90

Zulfah, Z. (2017). Tahap Preliminary Research Pengembangan Lkpd Berbasis Pbl Untuk Materi Matematika Semester 1 Kelas Viii Smp. Jurnal Cendekia : Jurnal Pendidikan Matematika, $1(2)$, $1-12$. Retrieved From Http://Journal.Stkiptam.Ac.Id/Index.Php/Cendekia/Article/View/184 